NBER WORKING PAPER SERIES

THE ADAM KLUG MEMORIAL LECTURE:

HABERLER VERSUS NURKSE: THE CASE FOR FLOATING EXCHANGE RATES AS AN ALTERNATIVE TO BRETTON WOODS?

\author{
Michael D. Bordo \\ Harold James \\ Working Paper 8545 \\ http://www.nber.org/papers/w8545 \\ NATIONAL BUREAU OF ECONOMIC RESEARCH \\ 1050 Massachusetts Avenue \\ Cambridge, MA 02138 \\ October 2001
}

Prepared for the Conference: "The Open Economy Macromodel: Past, Present and Future." Ben Gurion University, Beersheva, Israel. June 18, 2001. The views expressed herein are those of the authors and not necessarily those of the National Bureau of Economic Research.

(C) 2001 by Michael D. Bordo and Harold James. All rights reserved. Short sections of text, not to exceed two paragraphs, may be quoted without explicit permission provided that full credit, including $\odot$ notice, is given to the source. 
The Adam Klug Memorial Lecture:

Haberler versus Nurkse: The Case for Floating Exchange Rates

as an Alternative to Bretton Woods?

Michael D. Bordo and Harold James

NBER Working Paper No. 8545

October 2001

JEL No. E22, B31, F33

\begin{abstract}
From the perspective of the late 1930s and 1940s the dominant view was that the inter-war currency experience was a financial disaster. The view is perfectly encapsulated in the League of Nations' publication The Inter-war Currency Experience, the bulk of which was written by Ragnar Nurkse and published in 1944. It was also the view behind the Keynes and White plans for international monetary reform, which culminated in the Bretton Woods conference and the establishment of the adjustable peg par value system buttressed by capital controls. An alternative view to Nurkse was posited by Gottfried Haberler in Prosperity and Depression, also commissioned by the League of Nations and published in 1937. In Prosperity and Depression Haberler made a strong intellectual case for floating exchange rates as a mechanism to insulate countries from the transmission of booms and depressions.

In this paper we consider the views of Nurkse and Haberler on fixed and floating exchange rates and consider why Haberler's approach was not taken seriously until 1950s. Our main conclusion is that Haberler himself failed to offer a sufficiently clear blueprint for his approach at the time, although he did come to it by 1953. Moreover his views were counter to the ascending Keynesian paradigm.
\end{abstract}

Michael D. Bordo

Department of Economics

Rutgers University

New Brunswick, NJ 08901

and NBER

bordo@economics.rutgers.edu
Harold James

Department of History

Princeton University

Princeton, NJ 08544

hjames@princeton.edu 


\section{Haberler versus Nurkse: The Case for Floating Exchange Rates as an Alternative to Bretton Woods?}

Michael Bordo

Harold James

\section{Section 1. Introduction}

From the perspective of the late 1930s and 1940s, the dominant view was that the inter-war experience was a financial disaster. This view is perfectly encapsulated in the League of Nations' publication The Inter-war Currency Experience, the bulk of which was written by Ragnar Nurkse, published in 1944 and in the League's parallel 1945 publication, Economic Stability in the Post-War World. It also was the view behind the Keynes and White plans for international monetary reform, which culminated in the Bretton Woods conference.

According to this view:

- the floating exchange rate experience of the 1920s was marked by destabilizing speculation and instability

- the gold exchange standard did not work because it unilaterally imposed deflationary adjustment on deficit countries while surplus countries sterilized gold inflows, and because of a wrong choice of exchange rates after World War I, and because of a general shortage of gold 
- short term capital flows ("hot money movements") were destructive in the 1930s

- competitive devaluations in the 1930s ("beggar-thy-neighbor") were counterproductive

- all these factors destroyed the multilateral payments system and a movement toward bilateralism and autarky ("Schachtianism"), and the breakdown of international trade played an important role in the origins of the Second World War.

This perception of events led to the case for capital controls and an adjustable peg, or parities that could be altered in the case of fundamental disequilbrium. What would now be known as the "corner solutions" of gold standard rigid fixing or floating rates were rejected. The gold standard was criticized because it subordinated domestic goals such as full employment or price stability to external stability. Capital controls were required to prevent destabilizing speculation and to allow some degree of domestic policy autonomy. An international financial authority was needed to prevent harmful interactions between different national policies, or to further coordination of economic policy.

The Bretton Woods system was established, but it was only in the late 1950s and early 1960s that the major industrial countries made the transition to current account convertibility. It rapidly unraveled, because countries found it hard to identify fundamental disequilibria, or to change exchange rates. In the meantime, the exchange rate offered a nice target for speculation, which capital controls were in practice unable to control. As the U.S. provided the reserve center for the system, and as claims against the U.S. built up, the U.S. became the subject of possible speculative attacks. The clearly visible defects of the Bretton Woods system led to a case for generalized floating, a case 
which in fact had already been made in 1953 by Milton Friedman. ${ }^{1}$ By 1973, generalized floating provided the basis for a new system or non-system in international monetary relations.

Modern economic historians view the experience of the 1920s and 1930s differently. ${ }^{2}$ Exchange rate instability reflected destabilizing monetary and fiscal policies. Competitive devaluations were less disruptive to trade than was believed, and the fundamental problems came from high tariff levels and above all from quotas. The case of French floating in the 1920s was the outcome of political dissension about appropriate fiscal policy, and British floating in the 1930s was a clear success. Capital flows reflected underlying fundamentals, in which inconsistent policy mixes produced incredible policies that made currencies vulnerable to speculative attacks. The exchange rate system provided a mechanism for the transmission of monetary shocks.

Could there have been an alternative route to 1973? A strong intellectual case for floating had already been made earlier than 1953, in the work of Gottfried Haberler. He argued that a floating exchange rate could insulate countries from the transmission of booms and depressions. His view is a clear predecessor to the open economy FlemingMundell model.

Why was Haberler's analysis not taken more seriously at the time of the wartime discussions of a postwar monetary system. In part the answer is that Haberler was an analyst not an advocate, moreover he believed that the interwar experience with devaluation and floating was unsatisfactory because floating was associated with

\footnotetext{
${ }^{1}$ Friedman's "The Case for Flexible Exchange Rates" first appeared in a memorandum written in Paris in 1950. Others also advocated floating in this period, e.g. Emminger, Sohmen and British officials in the ROBOT plan. Canada's successful shift to floating in 1950 became a focal point for their view.
} 
destabilizing speculation. In part the answer is that his approach was viewed as anachronistic since it did not follow the Keynesian lead; and in part the 1930s was in the grip of a real terror about capital movements because they were so clearly and intimately associated with political crises. Indeed, in 1945, even Haberler subscribed to the NurkseBretton Woods consensus.

Section 2 examines the views of Nurkse and the Bretton Woods mainstream. Section 3 develops Haberler's analysis in the 1930s of the transmission of business cycles under fixed and floating rates and considers why, although he presented the case for floating, he was not an advocate. Section 4 looks at the resistance to Haberler's analysis of floating in the League of Nations and elsewhere. Section 5 concludes with a discussion of Haberler's postwar advocacy of the case for generalized floating, his critique of the adjustable peg and his reinterpretation of the events of the interwar.

\footnotetext{
${ }^{2}$ See Bordo (1993), pp. $30-31$.
} 


\section{Section 2. Ragnar Nurkse and the Bretton Woods Consensus}

The League of Nations, and in particular its Economic and Financial Organization, had played a major role in international economic relations in the 1920s. In the 1930s, however, the League was under attack. As a peacekeeper, it was undermined by its failures in regard to the Japanese invasion of Manchuria and the Italian invasion of Abyssinia, by the absence of the United States and the Soviet Union, and by the Nazi decision to leave the League and unilaterally pursue rearmament. In economic matters, the credibility of the League was undermined by the failure of the London World Economic Conference of 1933 (Clavin 1996). None of the suggestions for a tariff truce or for monetary stabilization seemed to stand much chance of success.

The League retreated into discussions of policy that might be appropriate in a national setting. In October 1937, it initiated a large scale inquiry into "measures which might be employed with a view to the prevention and mitigation of economic depressions." As part of this exercise, it initiated a series of discussions between a large number of prominent economists, which eventually resulted in the publication of a blueprint for a new economic order under the title Economic Stability in the Post-War World (1945).

Most of these discussions, and the book that Haberler had previously written for the League on Prosperity and Depression had their major emphasis on national policy, and not on international monetary arrangements. A League official, Pietro Stoppani, wrote that: 
"During recent years the type of work undertaken by the Economic and Financial Organization of the League has undergone a rather striking development. Political and economic circumstances have rendered difficult the conclusions of conventions and multilateral agreements ... This state of affairs has led the Economic and Financial Organisation to concentrate increasingly on the study of problems common to all countries as distinct from problems of international economic relations. The method which has been adopted has been that of expert, scientific enquiry into particular problems with which states are faced both internally and in their relations with other states."3

During the War, however, it became clear that an examination of international monetary issues would be critical for the making of the postwar settlement, and the League Economic and Financial Organization set about preparing a survey of interwar currency experience. That work was mostly written by Ragnar Nurkse.

It is worth thinking about Nukse's personal trajectory. Nurkse was born in Estonia of an Estonian father and Swedish mother, but his family emigrated to Canada and he stidued in Edinburgh and then in (crucially) Vienna, where he worked with the major figures of the Austrian school - Haberler, Hayek, Machlup, Mises and Morgenstern. Vienna was crucial; not only was it the center of a tradition of economics; but with the Creditandsalt collapse of 1931, it provided the epicenter of the world financial crisis. At a critical time for Nurkse, with the experience of banking and currency crises of 1931 , capital flight appeared as the pressing issue for contemporary economics. Machlup in

\footnotetext{
${ }^{3}$ LoN R4459, Stoppani, "Note Regarding the Possibilities of International Action in Economic Matters."
} 
1932 in Weltwirtschaftliches Archiv published a paper in which he examined how capital flight contributed to banking collapses as well as to obvious balance of payments difficulties, in that in order to make movements across the exchanges, speculators withdrew deposits from banks and endangered the banking systems. If central banks tried to compensate with increased liquidity for such withdrawals, they lost reserves and their exchange rate was endangered. Governments reacted with exchange controls, "police measures, penal sanctions and confiscation" which diminished the propensity to save, to invest capital, and added to the "psychological roots of capital flight."

Nurkse's first article was on the "Causes and Effects of Capital Movements", which became the basis for a book published in 1935. In the meantime he had moved to Geneva to a post in the League of Nations Financial Section, which moved from Geneva to Princeton during the War. At first he worked closely with Gottfried Haberler in Geneva too. In Princeton he was part of a team of distinguished economists including J.B. Condliffe, Marcus Fleming, Folke Hilgerdt, Jacques Polak, and Louis Rasminsky.

His major work in Princeton involved the preparation of a League Publication which was circulated in roneographed form to the delegations arriving in the summer of 1944 for the preliminary meeting at Atlantic City that prepared the agenda for the United Nations Monetary Conference at Bretton Woods. Except for Chapter VI (on Exchange Stabilization Funds) this book, International Currency Experience: Lessons from the Inter-War Period, was written by Nurkse, although it was extensively commented on by members of what had become the League's "Economic, Financial, and Transit Department", and in particular by the director of the department Alexander Loveday.

\footnotetext{
${ }^{4}$ Machlup (1932), p. 527.
} 
That book distilled a series of lessons from the interwar experience that lay behind the Bretton Woods solution. There is actually a strong personal link between the League, its lessons, and the new order. Indeed Nurkse was offered a senior position in the institutions created at Bretton Woods, the International Monetary Fund, which he turned down to take a chair in Columbia University; but a number of his colleagues at the League did go to the IMF. Some of them - especially Polak - saw the IMF as a continuation and extension of the experience and work of the interwar League.

According to Nurkse's interpretation, the circumstances of postwar reconstruction after the First World War held some crucial lessons for what should be avoided after the Second. In particular:

1. Much of the instability of the 1920 s stemmed from the exchange rate depreciations at the beginning of the decade. At first depreciations in the continental European economies stimulated the economies, by creating price advantages for export industries. Since the depreciated rates were believed to be temporary they attracted capital inflows. But as depreciation continued, and the prospect of a return to pre-war gold standard parities looked less and less likely, the advantages disappeared. Wages rapidly adjusted to depreciation and removed the cost advantage for exports. A "cumulative process of capital flight" began. Nurkse concluded that "exchange depreciation was a fitful and unreliable method of attracting foreign funds to replenish the national working capital, a method depending on the interplay of speculative anticipations" (115). The French franc in the 1920s offered a particularly intense example of 
how freely fluctuating rates could not be maintained "on an even keel" (119) but tended to overshoot.

2. When currencies were eventually stabilized in the mid-1920s, they were stabilized at the wrong levels. Again, this result had been produced by the perverse effects of capital movements. "The rates at which exchanges were fixed had been reached frequently under the influence of abnormal short-term movements with the result that some currencies were overvalued and others undervalued ... The two most familiar but by no means the only sources of disequilibrium arose from the successive stabilization of the pound sterling and the French franc early in 1925 and late in 1936 respectively, the one at too high and the other at too low a level in relation to domestic costs and prices." $(116-17)$

3. The 1920s lacked a proper system of coordination for achieving a stable set of exchange rates. "It was partly because of the lack of proper coordination during the stabilization period of the twenties that the system broke down in the thirties." (117) In part this absence of coordination reflected the absence of a hegemonic power. Here Nurkse sketches out an argument later associated with Kindleberger: "The gold exchange standard suffered from the coexistence of at least two centres. Shifts of reserves from one centre to another gave rise to gold movements, and the liquidity of each centre was therefore liable to strains." (217)

4. In the 1930 s, countries engaged in competitive devaluations in part to get trade advantages (beggar-thy-neighbor policies), but in large part also because the 
exchange rates were driven by "speculative capital movements." The countries concerned did not really want widely fluctuating rates, but there was no alternative: "the level at which official controls stepped in to steady the exchange by one means or another was often reached in quite abnormal conditions." (123)

5. The frequency of exchange adjustments was a major cause of the destruction of the international trading system. "The more frequent the exchange adjustments, the stronger are likely to be the disequilibriating tendencies not only in the capital flow but also in the movement of trade; the more frequent and disturbing will be the internal shifts of labour and other resources; the more seriously will exchange risks hamper foreign trade.” (141)

6. In the interwar system, international monetary policy had been increasingly set to conform with domestic objectives, in particular attempting to deal with the problem of unemployment, but this had produced the destabilizing depreciations and capital flows. A postwar monetary order would thus have to "find a system of international currency regulations compatible with the requirements of domestic stability.” (230)

7. Nurkse drew from these analyses the conclusion that first, initial exchange rates in "the establishment of an initial system should be made by mutual consultation and agreement", and second, that subsequent alterations should be as rare as possible, but should not be impossible. They "should not be altered by arbitrary unilateral action." (141) "Changes in exchange rates are 
likely to be the more effective the less frequently they occur. Exchange stability should be the norm and exchange adjustment the exception." (225)

It is striking that there is one continuous villain, which explains why cumulative depreciation got under way in the early 1920s, why stabilization took place at the wrong levels, and why competitive devaluations wracked the 1930s. That villain is the movement of capital. There seems to have been a general consensus among the League economists in this issue. The director of the EFO Alexander Loveday, explained that "international lending was a bad method of combating economic depressions. When times were bad, the default which eventually ensued intensified the existing depression and led to currency depreciation." He recommended a negative attitude on this point and personally preferred the export of capital on an equity, not on a bond basis. ${ }^{5}$

The argument expounded by Nurkse relies heavily on the idea that hot money flows, which had in particular been a concomitant of political crises in the 1930s and which were thus thought to undermine democracy and international peace as well as international economic relations, were triggered primarily by expectations of exchange rate movements. Nurkse uses a quotation to hammer his point home: "When ... national policies cease to regard the maintenance of exchange stability as something which must take precedence over all other considerations, ... speculation regarding the probable movement of the exchanges, and capital movements in connection with such speculation, are normal and inevitable" (131). This quotation is from Gottfried Haberler's Prosperity and Depression (431). But Haberler's analysis really runs in a quite different direction.

\footnotetext{
${ }^{5}$ LoN R4453, June 30, 1938, Minutes of Delegation on Economic Depressions.
} 
Section 3. Gottfried Haberler and the International Transmission of Business Cycles

Gottfried von Haberler, born in Purkersdorf, Austria in 1900 was one of the leading members of the Austrian School of Economics. He studied at the University of Vienna in the early 1920's under Friederich von Wieser and Ludwig von Mises, and was a classmate of Friederich von Hayek, Oskar Morgenstern and Fritz Machlup. After receiving doctorates in Law(1923) and in Economics (1925), he spent two years studying in the United States and Great Britain under a Rockefeller Foundation grant. He returned to Vienna and taught there from 1928-1936. During that period he was also a Visiting Professor of Economics at Harvard (1931-1932) and held an appointment with the League of Nations in Geneva (1934-1936) that led to the publication of Prosperity and Depression. in 1937. Haberler moved to the United States in 1936 and became Professor of Economics at Harvard University where he remained until retirement in 1971. He spent the rest of his life (1971-1995) as Senior Scholar at the American Enterprise Institute in Washington D.C. ${ }^{6}$

Haberler's major contributions to economics were in the study of business cycles, the subject of this paper, ${ }^{7}$ in the theory of index numbers, and in the theory of international trade. ${ }^{8}$

Gottfried von Haberler's book Prosperity and Depression began as a short (47 pages) brochure produced as part of a major inquiry commissioned by the League of

\footnotetext{
${ }^{6}$ See Chipman (1987) and Ebeling (2000).

${ }^{7} \mathrm{He}$ is credited with first discussing the real balance effect in the 1941 edition of Prosperity and Depression as a way to avoid price level indeterminancy in the Keynesian model. ${ }^{8}$ According to Chipman(1987, p. 581) "his most significant contribution was his reformulation of the theory of comparative costs which revolutionized the theory of trade ".
} 
Nations, and funded by the Rockefeller Foundation, into the "Causes of Recurrence of Periods of Economic Depression”. It was circulated in August 1934, with an invitation to comment, to a substantial number of prominent economists, under the title "Analysis of the Theories of the Business Cycle". This paper included only a few introductory and general comments on international aspects of the business cycle, arguing that cycles had become international as a consequence of increased international interconnectedness. In particular, cycles might be linked through:

1. Changes in demand and supply of particular commodities.

2. Movements of capital. Haberler added the comment: "Here again it is not a priori clear that the influence is such that prosperity in country A tends to create prosperity in $\mathrm{B}$, and depression in $\mathrm{A}$ depression in $\mathrm{B}$. It is conceivable that prosperity in A draws upon the capital supply of B and has therefore an adverse influence on B.”

3. The international money mechanism ("the most important vehicle of prosperity and depression from country to country, the most powerful force which tends to bring about far-reaching mutual adjustment of the cyclical movement in various countries"). Haberler noted: "Countries which have adopted the same standard of value (which are on the gold standard), or, more generally speaking, have adopted the policy of keeping the exchange rate fixed (exactly or approximately), are bound to move in the same direction as far as expansion and contraction in the circulating medium is concerned. An expansion in one country will ease the 
monetary situation in another and will tend to drag it along in the same direction." 9

There is here no consideration of the role of monetary policy, and the whole passage is in fact rather unsatisfactory. Very few of the comments supplied by the economists took on this aspect of the paper, and most concentrated on the discussion of domestic anti-cyclical policies, the treatment of Keynes, and the relationship between saving and investment (and the problematical definition of these terms, which Haberler used in a different sense than did Keynes). Only Alec Macfie wrote to Haberler to ask for more on the international side: "It seems to me that your work will be most valuable if it concentrates on the international aspects of the system. We in Britain feel, I think, that if the cycles were a purely internal matter, then our banking system could control it." ${ }^{\prime 10}$

The book manuscript of Prosperity and Depression, which developed on the basis of the 1934 paper, was circulated to a smaller circle of economists: D.H. Robertson, Tinbergen, Robbins, Morgenstern, Bresciani-Turroni, Dupriez, Rist, Ohlin, Hansen, J.M. Clark, and Oskar Anderson. ${ }^{11}$

\subsection{International Business Cycles under Fixed Exchange Rates}

In Prosperity and Depression, (1937 and subsequent editions), chapter 12, Haberler analyzed the international characteristics of business cycles. His methodology was to start with the assumption that the world consisted of sovereign nation states that

\footnotetext{
9 League of Nations archive, Geneva, R4539, Haberler, Systematic Analysis of the Theories of Business Cycles (August 1934, Economic Intelligence Service), p. 3.

${ }^{10}$ LoN R4539, Jan. 5, 1935, Alec. Macfie to Haberler.
} 
used a common currency and that there were no impediments to the movement of goods and factors of production. From that simple perspective he then introduced, one by one, the real world complications of tariffs and transportation costs; impediments to capital mobility; and national currencies and alternative monetary standards. Within each of these categories he then analyzed the international transmission of shocks ( both real and monetary).

We focus on the role of monetary standards. ${ }^{12}$ Haberler (425-427) analyzes international transmission first treating the world as a unified currency area ( using gold coins as currency with bank money convertible into coin) without and then with national central banks (such as the present day European Union). Without impediments to capital mobility, transmission of real shocks occurs via gold flows amplified by capital flows. Central banks have no scope for neutralization. The only role for an independent monetary policy is " if credit is localized" (428). Under this circumstance central banks can temporarily sterilize gold flows but they are limited by the size of their gold reserves in the case of an outflow, and the stock of government securities in the case of an inflow.

Next Haberler assumes a world close to the classical gold standard in which each country has its own national currency fully convertible into gold (430). The analysis of transmission and insulation is the same as that of the unified currency area. However here he introduces the possibility of destabilizing capital flows, if the commitment to gold is not completely credible." [t]he mere anticipation or apprehension of exchange rate variations will suffice to give rise to speculative movements of capital from one currency to another"(430). Indeed here he clearly distinguishes between stabilizing short-term

11 LoN R4539, Feb. 10, 1936, Loveday note. 
capital movements "if it is believed that no change will take place in the exchange rate"13 and destabilizing speculation in the case where

“the adverse development of A's balance on trading account is expected to be sufficiently considerable and sufficiently lasting to cause a transfer of gold from A to B on such a scale as to lead to the abandonment of the gold standard by A. There will be a flight from A's currency to B's which will accentuate the gold export and either advance the day when the gold standard must be abandoned or force A to a more severe deflation than would otherwise be necessary ... Anticipations regarding movements in the foreign exchanges tend to their own fulfillment." ( 431)

\subsection{International Business Cycles under Floating Exchange Rates}

The fixed exchange rate standard is then compared to a world of freely floating exchange rates. Before analyzing a free float, Haberler considers devaluation from a fixed exchange rate as a deliberate policy action. Two cases are distinguished. The stable case where it is believed that the devaluation is expected to be permanent, and the unstable case where it is believed that the devaluation is insufficient to restore balance of payments equilibrium. In the former case, a devaluation will be successful in improving the balance of trade and raising the level of income based on the implicit assumption that

\footnotetext{
${ }^{12}$ Also see Willett(1982) who covers some of the same ground.

${ }^{13} \mathrm{His}$ analysis is close to the recent literature that views the classical gold standard as a form of credible target zone. See Hallwood, Marsh and MacDonald (1996) and Bordo and MacDonald (1997).
} 
the demands for both imports and exports are elastic. ${ }^{14}$ Moreover capital inflows will speed up the adjustment. Opposite effects will occur in appreciating countries. The net effect for the world as a whole depends on whether the devaluation " corrects an overvaluation" of the depreciated,and an "undervaluation" of the appreciated currency." (439)

In the second case, which Haberler (436) and also Haberler $(1936,44)$ believes is much closer to the interwar experience, a devaluation which is not believed to be sufficient to restore equilibrium will lead to capital flight and to instability in the exchange markets. In this case capital flows will have a deflationary effect on the world as a whole. (440)

Haberler (441-451) then turns to the case of floating exchange rates ("free floats"). Although he states that "it is not suggested that such a system has ever existed in a pure form" (411), he views the analysis of business cycles under floating as valuable because of the contrast with the gold standard. Under a free float, equilibrium in the balance of payments is maintained by variation in the exchange rate whereas under the gold standard equilibrium requires gold flows. ( 442)

Haberler compares the transmission of real shocks ( a change in tastes or a change in investment demand) under floating and under the gold standard, in the case where capital is immobile (443). If there is a shift of demand from country A's products to those of country B, the following occurs under floating: the value of A's currency falls relative to that in $\mathrm{B}$. Assuming elastic demands for exports and imports, the exchange

\footnotetext{
${ }^{14}$ In Haberler(1949) a strong case is made against" elasticity pessimism".
} 
rate completely equilibrates the balance of trade. This is compared to a gold standard where a gold flow is required to restore equilibrium.

"By reasoning not essentially different from the above, it can be shown that, under free exchanges without capital movements, there will be no tendency for prosperity or depression to communicate itself from country to country “ ( 446)

and after analyzing the effect of an investment boom in country B on country A he states

"The free-exchange system eliminates from the economic interchange of different countries the most important carrier of the boom and depression bacillus- namely the flow of money across frontiers."

Thus a key implication of Haberler's analysis [although he didn't state this at the time] is that floating exchange rates could have prevented the international transmission of the Great Depression.

Haberler later qualifies his analysis of the insulation properties of floating rates. In a passage which nicely presages the analysis of Mundell (1963), he demonstrates that if capital is completely mobile that real shocks (such as an investment boom) will be internationally transmitted as under the gold standard but that changes in monetary policy can lead to perverse effects on other countries. At the same time however 
domestic monetary authorities have the leeway to stimulate the economy unlike under the gold standard.

"Suppose that a boom flares up in country D because new investment opportunities have appeared. If this attracts foreign capital, the expansionary stimulus is at once transmitted to the other ( capital exporting countries), while the expansion is hampered in the country $\mathrm{D}$, where the stimulation first arose. If on the other hand the expansion in $\mathrm{D}$ is brought about or fostered by a cheap money policy and if thereby capital is driven out of the country $\mathrm{D}$ (to take advantage of the higher interest rates abroad), the expansion in D is further intensified by the outward capital movement. The outside world instead of basking in the rays of prosperity cast by $\mathrm{D}$, feels a chilling wind from that quarter and may even be thrown into a vicious spiral of deflation" (449).

Compare this analysis to that of Mundell (1963), and also Meade (1951) and Fleming(1962), where under floating exchange rates with perfect capital mobility,although a rise in the domestic money supply creates an incipient balance of payments deficit at home and surplus abroad leading to a depreciation of the home currency,the concomitant decline in interest rates induces a capital outflow which further depreciates the home currency. Demand for the home country's goods is thereby stimulated and demand for the foreign country's goods is reduced, raising income at 
home and reducing it abroad. ${ }^{15}$ With capital mobility, monetary expansion at home leads to a recession abroad.

Under floating exchange rates, an increase in government expenditure in one country raises real expenditure including the demand for imports, hence depreciating the exchange rate. With capital mobility, however, the rise in interest rates induced by the increase in government expenditure leads to a capital inflow, which offsets the effect of the current account imbalance on the exchange rate. At the same time, the capital outflow from the foreign country depreciates its exchange rate, stimulating the demand for its goods. Hence real output abroad rises. ${ }^{16} \cdot{ }^{17}$

\subsection{What did Haberler Really Believe about Floating Exchange rates?}

A reading of Prosperity and Depression chapter 12 leads to a schizophrenic interpretation of Haberler's views on floating rates. On the one hand, the quotation from page 431 that Nurkse used in his attack on them, gives the impression that Haberler himself was also very opposed. This is also echoed in his earlier book The Theory of International Trade (1936) where he states:

"Both commercial and financial relations with foreign countries are at once sensibly affected by flutuations of the exchanges. Speculation in the foreign exchange market develops, unless rates are kept absolutely stable, and

\footnotetext{
${ }^{15}$ The negative spillover effect is smaller the larger the domestic economy.

16 This spillover effect diminishes the larger is the size of the domestic economy.

${ }^{17}$ See Bordo and Schwartz(1990).
} 
international credit-operations of a normal kind are seriously hampered thereby."

On the other hand, from a reading of the discussion of free floating from pages 441-451 in Prosperity and Depression covered in section 3.2 above, Haberler succinctly analyzed the role that floating could provide as an insulator against international disturbances and as fostering the conditions for monetary independence.

Which Haberler are we to believe? The answer lies in the perception of the events of the interwar period that Haberler and his contemporaries all had — that departures from the gold standard occurred in the face of serious speculative attacks, that devaluations were almost always accompanied by capital flight, and the French experience with floating as a free-fall. They did not seriously consider the connection between unstable fiscal and monetary policies and unstable exchange rates or the possibility that stable financial policies could foster stable floating rates.

Haberler himself was strongly influenced by the events in central Europe that he had previously experienced. In The Theory of International Trade he writes:

“In financially weak countries- particularly where the memory of inflation is still fresh- every deviation of the exchange rate from gold parity, or even any likelihood of such deviation must lead to a crisis of confidence and to withdrawals of credit. This has been demonstrated once more by events in Germany in 1931 and 1932." 
Yet he was also aware of the successful experience that England had with floating after September 1931:

"Since departing, in September 1931, from the gold standard, England has followed more or less deliberately and with the support of many English economists a policy of stabilizing the price level. This policy enabled the Scandanavian countries and the Dominions to reap the advantages of stable rates with England-still the center of world trade- and with other members of the sterling- group, and to maintain stability of prices relatively to one another." (45)

However, he goes on to say that

" the instability of the exchange rate between the gold-standard and the sterlingcurrencies has led to serious disadvantages. The conclusion seems therefore justified that stable exchange- rates, or in other words an international standard of one kind or another, is indispensable in the long-run for any extensive exchange of goods and credit on an individualistic basis " (46)

Thus Haberler, like Nurkse, was a captive of the contemporary perception of the tumultuous events of his time. In Prosperity and Depression his analysis led to the theoretical possibility that floating exchange rates could have cut short the international transmission of the Great Depression but he did not state this. Thus although Haberler 
laid the intellectual ground work for the case for floating it seems unlikely that he would have been its advocate before World War II.

Indeed in an article written at the end of World War II for a panel session of the American Economics Association considering post war policies, Habeler made a strong statement against floating

"... it is certain that a system of "free exchanges" would lead to extremely undesirable results. It would incite capital flight and violent fluctuations. There are very few instances of really free exchanges in monetary history and none that could be called successful... such a free system would be even worse this time [ compared to the French case after World War I] because people everywhere are much more inflation conscious than they were in 1919 , and hence, speculative reactions would be very quick “ $(1945,209)$

In sum, although Haberler definitely presented a clear alternative to the adjustable peg with capital controls that the world adopted at Bretton Woods in 1944, it seems unlikely that he would have been the person to advocate it.

\section{The Contemporary Response to Haberler}

In Prosperity and Depression, Haberler intended to synthesize existing theory. Partly underlying this work of synthesis was an intention to demonstrate that Keynes was not as original as his supporters claimed, and there was thus an implicit polemic, which 
the Keynesians recognized. The Keynesians recognized this, and Richard Kahn complained in an Economic Journal review (1937, p. 677) of Haberler's "basic ideology"; while Haberler's best Cambridge contact was Dennis Robertson, who described himself as a "black sheep" in Cambridge because of his skepticism about the multiplier. ${ }^{18}$ On the other hand, there was quite widespread recognition of the attraction of such a synthesis. Arthur Burns responded to the 1934 paper with a "wish to congratulate you upon your success in showing that the differences among the various theories are far less important than is commonly assumed." 19 The emerging Keynesian Roy Harrod spoke of the "idea of arbitration" and "conciliation" and added: "I myself have often advocated that something of this sort should be done in cases of disputes among economists." 20

Partly, also, Haberler was instructed by the League's Economic and Financial Organisation, and its influential director Alexander Loveday, to avoid polemics. When in 1939 Haberler revised Chapter 8 in an anti-Keynesian sense, Loveday rebuked him: "You give the impression of a valiant and war-scarred chieftain, gathering around him his plaid and his followers in order to make one fierce and final attack upon his adversaries. This, I think, can be successful as a diplomatic form of procedure on the assumption that the adversaries are in fact decimated to a man. But, alas, whatever the prospects of decimation may be, this is not a procedure that the League as a publisher can possibly contemplate. We cannot enter into professorial politics. ${ }^{21}$ In fact the whole League

${ }^{18}$ LoN R4539, April 16, 1936 Robertson to Keynes.

${ }^{19}$ LoN R4539, Dec. 27, 1934 Arthur F. Burns to Haberler.

${ }^{20}$ LoN R4539, Nov. 5, 1934 Harrod to Haberler.

${ }^{21}$ LoN R4540, Feb. 10, 1939, Loveday to Haberler. 
project involved getting as many prominent economists as possible to argue and comment on each other's work, and to produce what might be thought of as a new consensus.

It is striking how little commentary the international sections of the book occasioned in the mid-1930s: again all the discussion focused on the Keynesian discussion, and on Haberler's use of time periods, and on whether Haberler was too Austrian (Einaudi wrote "Money seems to be the moving deity. And so it is to a certain point."). ${ }^{22}$

Haberler continued to be central to a new League project, which fundamentally developed the study of Prosperity and Depression, which was adopted by the Council of the League in January 1938, "to conduct an enquiry into measures that might be deployed with a view to the prevention or mitigation of economic depressions."

This new project not only drew in the views of economists; every finance ministry and central bank in the member countries of the League were invited to make a statement. Commenting on the replies to this invitation, the League's Economic and Financial Organisation concluded, "the most remarkable feature common to practically all Government replies is the absence of definite statements regarding the adoption of exchange depreciation as a deliberate measure of monetary policy." (The only exception was Chile, whose central bank provided a quite definite statement:

"A policy which has as its conscious aim not only the maintenance of relative stability in the purchasing power of the currency, but also greater stability in the development of economic activity in general, can only achieve that aim provided 
that the maintenance of a legally stable monetary parity is ruled out a priori, and provided that the Government is authorized to modify the parity as the circumstances of a given situation may advise of dictate." $)^{23}$

This Chilean view was discarded as being eccentric, however; and in response to the big politically driven hot money movements of 1936-8 a new academic view was gradually formed, which Dennis Robertson summed up as "the deadliness of the weapon of competitive devaluation". ${ }^{24}$

The project on prevention and mitigation of crises continued during the War, when the League's Economic and Financial Organisation moved to Princeton. Haberler, who had long before moved to the United States (to a professorship in Harvard), worked during the War at the NBER. He continued to work with the project, and also quite closely followed a project conducted under the auspices of the League on lessons to be derived from interwar currency movements. The chief author for this project (originally entitled “The total volume of international currency") was Ragnar Nurkse, and Haberler maintained a regular correspondence with him, urging particular points (such as the correct view that the British pound was NOT over-valued between 1925 and 1931, a view ignored by Nurkse in the final publication). ${ }^{25}$ In general, Haberler was extremely supportive, and at the end of December 1943 wrote on reading the introductory first chapter:

22 LoN R4539, Jan. 28, 1935, Einaudi to Haberler.

${ }^{23}$ LoN D.D.E., Sept. 5, 1938, statement of central bank of Chile; Nov. 11, 1938, Summary of Government Replies.

24 LoN May 30, 1938 Robertson: Note on Measures to Promote Recovery from Depression.

${ }^{25}$ LoN C1738, Oct. 11, 1943, Haberler to Nurkse. 
"It seems to me an excellent piece of work and I have literally no comments. I am sure that the volume will arouse much interest and you should make sure that a bound edition will be available not only a brochure. Bound books sell much better than brochures. ${ }^{, 26}$

But there was a substantial pressure on Nurkse to distance himself from the Haberler stance, and to come down very emphatically on the side of a fixed exchange rate regime as an answer to the ills of competitive devaluation. That pressure came above all from a young Dutch economist, who had worked with the League in Geneva, and was now part of the Dutch government in exile (in the Economic, Financial and Shipping Mission of the Netherlands, in Washington D.C.), J.J. Polak. Polak wrote to Nurkse emphasizing his criticism of the exchange rate section of the draft:

"That is that it is taking rather a wavering attitude with regard to the desirability of exchange rate depreciation. I must say that I am personally rather in sympathy with this uncertain attitude; it reflects in fact the uncertainty of economic theory concerning this issue. However, for the benefit of the reader you might consider to tip the scales further against depreciation, provided 1) adequate measures are taken to prevent depressions and 2) there is an international mechanism to provide foreign exchange when required. The latter provision would take care of the balance of payments difficulties which depreciation is supposed to remedy. [This 
mechanism would be the IMF.] With respect to the stimulation of employment, you might again insist upon investment policies rather than depreciation."

This is a remarkable argument (or non-argument) in the way that it admits the "uncertainty" of economic theory on the exchange rate issue, but suggests that the "reader" would somehow benefit from a clearer stance against exchange rate movements. Indeed the influence of Haberler was to be excised: "Page 17, second paragraph, I would omit the six lines referring to Haberler, since they are a) not relevant and b) not true (at least this is my strong suspicion).,27

Polak reverted to this theme in subsequent correspondence with Nurkse. In dealing with balance of payments adjustment, he said, "You know the objections I feel against Haberer's [sic] treatment in 'Prosperity and Depression' and I think it would be a pity if the League would produce again a survey of this theoretical point which was long enough to pretend to be a standard treatment and which would yet not cover questions adequately. ${ }^{, 28}$ Fortified in this way, Nurkse proceeded to give an authoritative and scintillating account of the speculative ills associated with exchange rate movements.

\footnotetext{
${ }^{26}$ LoN C1738, Dec. 21, 1943, Haberker to Nurkse.

${ }^{27}$ LoN C1738, Aug. 25, 1943, Polak to Nurkse.

${ }^{28}$ LoN C1738, April 13, 1944, Polak to Nurkse.
} 


\section{Section 5. Conclusion: Haberler a Belated Advocate of Floating}

Two decades after The Theory of International Trade and Prosperity and Depression Haberler_came out as a strong advocate for floating exchange rates and he reversed a number of the positions he had taken in the 1930s and 1940s ${ }^{29}$ In Currency Convertibility (1954), Haberler makes the case that the European countries should remove their exchange controls and restore current account convertibility but not to the adjustable peg of the Bretton Woods Articles. Instead they should adopt floating rates as had been done by Canada in 1950. The case that he makes against the adjustable peg is very similar to that of Milton Friedman (1953):

"The system of the "adjustable peg' under which there are occasional sharp adjustments in the exchange rate of a currency while rates are rigidly pegged at a constant level during the intervening period... has worked in an unsatisfactory and in fact unstabilizing fashion." (24)

Like Friedman, Haberler criticizes the adjustable peg because the concept of'fundamental disequilibrium'- the criterion governing an adjustment in parity, is imprecise and monetary authorities " to avoid the embarassment of having to repeat the operation will tend to devalue too much rather than too little. Therefore the method of the 'adjustable peg' does not provide the necessary flexibility “ (24); it is highly vulnerable to speculative attack because speculators can only win with a one way bet against the peg; 
that " it puts responsible people in a morally dubious position. Up to the last moment before they carry out their decision to depreciate they have to protest solemnly that they have no such intention..." (25) As prime examples of the flaws in the Bretton Woods system, he cites the British crises of 1947 and 1949.

"'When a currency is under pressure, as Sterling was in 1949, the country loses gold and dollar reserves and more and more people expect a depreciation. If the currency is pegged, the risk of speculation against it is almost entirely removed, because the speculator can be virtually certain that the value of the currency will not go up. If Great Britain had possessed a floating exchange, the dollar price of Sterling would have drifted down earlier. There would also have been some speculation against Sterling. But soon a point would have been reached where some speculators would begin to expect recovery." $(25)^{30}$

Moreover as a contrast to the 1947 and 1949 experiences and in a partial reversal of his position in 1936, he praises the British float after 1931 as " another highly successful experiment in freely floating exchange rates, and in another reversal of his earlier views, he states that " persistent and massive speculation against a currency " capital flight" is invariably the consequences of inflation, policies, political instability or the threat of war" and not the consequence of floating [our emphasis] (24).

\footnotetext{
${ }^{29}$ In the late 1960s, Hebeler headed a committee to advise the incoming Republican administration on international monetary issues, and at this time pushed the case for floating.

${ }^{30}$ This of course echoes the controversial ROBOT plan circulated in 1952 inside the British government, urging the authorities to float the pound, make it convertible into gold and dollars, and fund the sterling balances (see Cairncross 1985, ch. 9).
} 
Finally, like Friedman, Haberler argues that in normal cases, floating would involve few changes in exchange rates and that" the inconvenience of fluctuating rates can be substantially reduced by permitting and organizing well functioning forward markets in foreign exchange " $(26)$

Two decades later, Haberler revisited the scene of the crime-the interwar period. In “The World Economy,Money and the Great Depression “ (1976), Haberler clearly states that floating rates were not to blame for the instability of that era.. He is highly critical of the Nurkse view that intertwined floating exchange rates with competitive devaluations as important causes of world depression.

"There has been general agreement that competitive depreciation of currencies greatly contributed to the world depression. This agreement found its expression in the Articles of Agreement of the International Monetary Fund... But the IMF charter does not define the term. It is indeed an imprecise term and there has been much confusion about its meaning and causes. Competitive depreciation has been and often still is attributed to floating... Some regard the mere existence of exchange-rate changes in the 1930s as evidence of competitive depreciation. This completely confuses the problem. Not every devaluation was of a competitive kind. A devaluation which merely restores equilibrium or "clean " unmanaged floats... has nothing to do with competitive devaluation" (385) Indeed the deflation and devolution of trade in the 1930's reflected the perverse operation of “an adjustable peg with excessive rigidity “ (387) 
Haberler describes the events of the 1930's as follows:

"The depreciation of the pound came in 1931,of the dollar in 1933-34,of the gold bloc currencies in $1936 \ldots$ In between the big changes, there was some movement of exchange rates, but very little free floating. Most of the devaluations were forced by acute balance of payments pressures intensified by massive speculation and could be justified as necessary conditions for domestic expansion and relaxation of import restrictions. But each of these devaluations put deflationary pressure on all the other countries that maintained their gold parities, pushing them deeper into depression import restrictions, and exchange control. This vicious sequence, [which ] became known as " competitive depreciation"... was attributed to floating, but in reality it was the consequence of overly rigid exchange rates- in other words, of the refusal to make adjustments until the situation became critical “ ( 375$)$

Thus " the major misinterpretation of the lessons was blaming the competitive depreciations of the 1930"s on flexible exchange rates rather than an excessive rigidity of those rates and on the defects of the method of the adjustable peg. As a consequence floating was ruled out." (390)

Haberler (1976) largely attributes the Great Depression to monetary forces and specifically, following Friedman and Schwartz(1963) to the monetary collapse in the United States. “ ... there can be no doubt that the collapse of the banking system, the bankruptcy of many thousand banks, and the inept and overly timid monetary policies 
which permitted the money stock to shrink by about one-third was to a large extent responsible for the disaster “ (384) The monetary collapse in the US. was then transmitted via the fixed exchange rate gold standard to the rest of the world. " The overwhelming importance of the monetary factor is underlined by the fact that countries that applied expansionary measures under the cover of open or disguised devaluation or of floating managed to extricate themselves from the maelstrom of deflation one or two years ahead of the United States “ $(385)^{31}$

Haberler is critical of the Nurkse view, which he had also endorsed earlier, ${ }^{32}$ that the international depression could have been avoided " if the leading industrial nations had initiated... a simultaneous policy of monetary expansion, in say, the spring of $1931 \ldots$ "(Nurkse, 1944,130). According to Haberler " the conditions needed for there to be sufficient policy coordination to obviate exchange rate changes are very exacting- so exacting indeed that they are unlikely to be generally fulfilled between sovereign countries." Haberler (1976)'s preferred solution is exactly the one implied by Haberler (1937)'s pages 441-451 discussion that the spread of the Great Depression could have been avoided by floating rates.

"Given the American depression and given the impossibility of an across the board change in gold parities, the best method of currency realignment would have been extensive floating. If in September 1931 Germany and the gold bloc countries, following the British example, had depreciated their currencies against the dollar and started expansionary policies, they all could have cut short the 
deflationary spiral in their countries, just as the devaluation of the pound cut short the deflationary spiral for the sterling bloc. This would have course intensified the US depression, but it might have induced the United States to take expansionary measures. “ $(377)^{33}$

Thus it took Haberler 40 years to fully make the case for floating exchange rates as the cure for the "bacillus" of the international spread of depressions, that his analysis in Prosperity and Depression suggested. Had he followed through at the time one wonders if the international monetary system would have evolved differently? Given the opposition to his analysis by most contemporaries it seems doubtful.

\footnotetext{
${ }^{31}$ For evidence see Bernanke and James (1991).

${ }^{32}$ And the view of Eichengreen (1992).

${ }^{33}$ Haberler (1976) footnote 29 also argued that the U.S. could have taken the required expansionary monetary policy to offset the deflation without being hampered by a balance of payments constraint. For recent supporting evidence see Bordo, Choudhri and Schwartz (1999) and Hsieh and Romer (2001).
} 


\section{$\underline{\text { References }}$}

Ben Bernanke and Harold James ( 1991) “The Gold Standard, Deflation, and Financial Crisis in the Great Depression: An International Comparison " in Financial Markets and Financial Crises (ed) R. Glenn Hubbard Chicago: University of Chicago Press. pp 33-68.

Michael D, Bordo ( 1993) “ The Bretton Woods International Monetary System: An Historical Overview" chapter 1 in A Retrospective on the Bretton Woods System:

Lessons for International Monetary Reform . (eds) Michael D. Bordo and Barry Eichengreen. Chicago: University of Chicago Press. pp 3- 98.

Michael D. Bordo and Anna J.Schwartz ( 1990) "Cyclical Effects of International Transmission of Real and Monetary Disturbances " in Analyzing Modern Business Cycles : Essays Honoring Geoffrey H. Moore (ed) Philip A. Klein. Armonk N.Y. M.E. Sharp pp 275-292.

Michael D. Bordo and Ronald A. MacDonald ( 1997) “Violations of the Rules of the Game and the Credibility of the Classical Gold Standard, 1880-1914" NBER Working Paper No. 6111. July

Michael D. Bordo, Ehsan Choudhri and Anna J. Schwartz ( 1999), “Was Expansionary Monetary Policy Feasible During the Great Contraction? :An Examination of the Gold Standard Constraint “ NBER Working Paper No. 7125 May. 
Alexander Cairncross ( 1985) Years of Recovery : British Economic Policy, 1945-1951. London: Methuen

John Chipman ( 1987) “ Gottfried Haberler “ New Palgrave Dictionary of Economics London: MacMillan

Patricia Clavin (1996) Failure of Economic Diplomacy : Britain, Germany, France and the United States 1933 -1936. New York : St. Martin's Press.

Richard M. Ebeling (2000) " Gottfried Haberler: A Centenary Appreciation " The Freeman Foundation for Economic Education Vol 50. No.7.

Barry Eichengreen ( 1992) Golden Fetters._New York: Oxford University Press.

John M. Fleming ( ( 1962) “ Domestic Financial Policies Under Fixed and Under Floating Exchange Rates “ IMF Staff Papers 9 (November) 369-79.

Milton Friedman ( 1953) “The Case for Flexible Exchange Rates" in Essays in Positive Economics. Chicago: University of Chicago Press

Gottfried von Haberler ( 1971) [1936] The Theory of International Trade : With its Application to Commercial Policy, New York. Augustus M. Kelley. 
Gottfried Haberler (1956) [1937] Prosperity and Depression: A Theoretical Analysis of Cyclical Movements. London: George Allen and Unwin

Gottfried Haberler (1945) “ The Choice of Exchange Rates after the War". American Economic Review. Vol 35 Issue 3 ( June), pp 308-18.

Gottfried Haberler ( 1949) "The Market For Foreign Exchange and the Stability of the Balance of Payments : A Theoretical Analysis “Kyklos, IIII: pp 193-218.

Gottfried Haberler ( 1954) Currency Convertibility. Washington D.C. : American Enterprise Association.

Gottfried Haberler ( 1976) “The World Economy, Money and the Great Depression”. chapter 16 in Selected Essays of Gottfried Haberler (ed) Anthony Y.C. Koo. Cambridge: M I T Press. pp 363-403.

C. Paul Hallwood,Ronald A. MacDonald, and Ian Marsh ( 1996), "Credibility and the Fundamentals:Were the Classical and Interwar Gold Standards Well Behaved Target Zones?" in Modern Perspectives on the Gold Standard (eds) Tamim Bayoumi,Barry Eichengreen and Mark_Taylor. Cambridge: Cambridge University Press.

Chang-Tai Hsieh and Christina Romer ( 2001) “Was the Federal Reserve Fettered? 
Devaluation Expectations in the 1932 Monetary Expansion" NBER Working Paper No.8113. February.

League of Nations (1945) Economic Stability in the Post- War World: The Conditions of Prosperity After the Transition from War to Peace. Report of the Delegation on Economic Depressions Part II.

Ragnar Nurkse (1944) International Currency Experience: Lessons of the Interwar Experience. League of_Nations: Geneva

Fritz Machlup (1932) “Die Theorie der Kapitalflucht “ Weltwirtschaftliches Archiv 36

James Meade ( 1965) [1951\} The Theory of International Policy V.1 ( Supplement), The Balance of Payments. London. Oxford University Press.

Robert A. Mundell (1968) \{1963] “Capital Mobility and Stabilization Policy Under Fixed and Flexible Exchange Rates" Chapter 17 in International Economics. Chicago: University of Chicago Press

Thomas D. Willett ( 1982) “ Gottfried Haberler on Inflation, Unemployment and International Monetary Economics: An Appreciation” . Quarterly Journal of Economics Vol 97. Issue I ( February) pp 161-169. 